\title{
The Effect Of Self-Efficacy And Gender On The Work-Family Balance Of Employees In Yogyakarta
}

\author{
Nina Zulida Situmorang \& Fauziah Wijayanti \\ Faculty of Psychology, University of Ahmad Dahlan \\ nina.situmorang@psy.uad.ac.id
}

\begin{abstract}
Abstrack. This research paper aims to discover the effects of self-efficacy and gender on the work-family balance levels of employees working in Yogyakarta. The research subjects consisted of 76 employees, half of them are male and the other half are female, working in both public and private sectors. The methods used in this research are quantitative methods. The data was collected by using two scales, which are work-family balance scales and self-efficacy scales. The chosen data analysis technique in this research is regression analysis using SPSS. The results of the research show that self-efficacy that is based on gender does have an effect on work-family balance, with an $\mathrm{R}=0.464$ with the value of $p=0.014(p<0.05)$. There is a correlation between self-efficacy with work-family balance levels in female employees if it is controlled by $p=$ $0.022(p<0.05)$. However, self-efficacy has no effect to work-family balance levels in male employees if it is controlled by $p=0.058(p>0.05)$
\end{abstract}

Keywords: Self-efficacy, gender, work-family balance.

\section{INTRODUCTION}

Employment is a basic necessity for every individual. The complex life of adults leads individuals to make difficult choices, especially as jobs begin to change and adapt to the current development of the world. It is also important to pay attention to challenges faced in employment that become increasingly difficult and resource-sapping as time progresses. This causes individuals to spend most of their time working, which unconsciously causes individuals to become complacent or stressed.

Employees are demanded to fulfill their duties to the best of their ability in order to be more productive and to increase the quality of the company as a whole. However, besides their job, families are also an important aspect of an employee's life. One of the risks faced by employees that spend a majority of their time working is the lesser amount of time to spend with their families. Drained levels of energy and the difficulty to allocate time equally can cause many problems. Furthermore, married employees that have more duties and responsibilities tend to have conflicting roles as an employee and as a member of a household. These conflicting roles will affect the employee's job satisfaction, as proven in research conducted by Warroka and Febrilia (2014).

Research conducted by Paramita and Waridin (2006) discovered that work-family balance has a partial positive effect and is significant to job satisfaction. These results are supported by statements made by Grzywacz and Carlson (2007), which stated that achieving ideal work-family balance can give several positive organizational benefits, such as increased commitment to the organization, higher levels of job satisfaction, and better organizational citizenship behavior (OCB).

Research by Ezra and Deckman (1996) showed that work-family balance is a component of job satisfaction. Higher levels of satisfaction can contribute positively to organizational commitment, job involvement, mental and physical health, and levels of quality of life (QOL) in both work and family situations. This in turn creates positive effects for the company, such as higher productivity levels and better employee performance. Job satisfaction also can contribute to the advancement and development of the company as a whole.

Grzywacz and Carlson (2007) also found that better work-family balance meant lesser tendencies to resign and lower absence levels. In addition, for their positive impacts to the firm, work-family balance also positively contributes to the personal lives of employees, as found by research conducted by Delina and Raya (2013) that showed the importance of work-life balance and the importance of said work-life balance for happiness and satisfaction in life.

Greenhause, Collin \& Shaw (2003) defined work-family balance as an employee's equal ties to their work responsibilities and their familial life. Marks and MacDermid (1996) interpreted workfamily balance as a factor involved in the performance of an individual in their multiple roles, and how an approach of an individual to their role as an employee and to their role as a family member should be caring and attentive. Kirchmeyer (Kalliath and Brough, 2008) stated that workfamily balance is the achievement of satisfaction in all aspects of life, in which the effort to achieve such satisfaction requires energy, time, and commitment to be allocated equally to all aspects. Greenhaus, 
Collins and Shaw (2003) divided work-family balance into three main components, which are: time balance, involvement balance, and satisfaction balance.

When gender becomes a factor, the difference in work-family balance between male and female employees becomes clear. The gender roles that are imposed on female employees have a more significant impact on their work-related behavior when compared to their male counterparts. Societal roles are derived from the social position of an individual and the norms that apply within the society. According to Baron and Byrne (1997), roles are the differentiation of functions within a certain group, where different members do different tasks, and in different groups, fulfill different roles with different tasks as well. Research by Adams, King, and King (1996) showed that when there are conflicting work-family roles, female employees derive less job satisfaction compared to the male employees. This also introduced the concept of the importance of balancing work and family roles as one of the choices made by individuals when taking care of their families, Sanders (1998).

One factor that can affect work-family balance is self-efficacy. Bandura (Feist, 2013) defined selfefficacy as one's confidence in their ability to control themselves and their surroundings. According to Hjelle \& Zieger (1992), self-efficacy is an individual's self-evaluation of their ability to face tasks and certain situations. Self-efficacy according to Santrock (2007) is an individual's belief in their ability to take control over situations and create beneficial results.

When self-efficacy levels are high and the surrounding environment is responsive, there is a high likelihood that ideal results will be achieved. When self-efficacy levels are low and the surrounding environment is responsive, individuals may feel depressed due their observation that others can successfully complete difficult tasks while they cannot. When individuals with high levels of selfefficacy enter unresponsive environments, there tends to be an effort from the individual to change their surrounding environment (Feist, 2013). Stajkovic and Luthans (Luthans, 2011) stated that self-efficacy reflects an individual's belief and confidence in their ability to mobilize motivation, to complete cognitive tasks, and to do the necessary actions required to successfully complete specific tasks in a certain context.

Bandura (Sulistiyawati, Hurtjahjanti \& Prihatsanti, 2012) mentioned three aspects of selfefficacy, which are: 1) Level, referring to variations of self-efficacy in various difficulty levels, such as in increasingly complex mathematical problems (Bandura, 2009). 2) Strength, which is an individual's confidence in their capability to perform at each level or component of the task given. 3) Generality, which is an individual's level of expectation that is either generalized over various situations or limited to certain tasks and situations.

Work-family balance is a situation where the responsibilities of an employee's job and family are at equal levels. All employees are expected to have high levels of work-family balance in order not to create conflicting roles as family members and as company employees. Work-family balance can be achieved when work necessities and familial necessities do not reduce work performance nor create household problems, which can in turn create work-related stress. (Dhamayanti, 2006).

Achieving work-family balance is also influenced by internal factors, one of them is selfefficacy. According to Bandura (Feist, 2013), selfefficacy is an individual's confidence in their ability to control themselves and their surroundings. An individual with higher levels of self-efficacy tend to be more satisfied with their work and their lives. Individuals with high levels of self-efficacy are often more confident of their ability to complete difficult tasks. Individuals with high levels of selfefficacy are also more confident of their ability to divide their time for their family and their career properly, as well as of their ability to handle arising problems (Nurtjahjanti, et al., 2012). This means that individuals with higher levels of self-efficacy have better work-family balance.

Based on the background, then the aim of this research is to see the effects of self-efficacy and gender on work-family balance of employees in Yogyakarta.

\section{RESEARCH METHODS}

The population of this research are employees that are married and have children, aged 30 to 50 years old, and work 6 to 8 hours per day. The sampling method used is incidental sampling, with 76 employees becoming the research sample. The measurements used in this research are the workfamily balance scale, self-efficacy scale, and gratitude scale. The work-family balance scale consists of 24 items and is arranged according to the components discussed by Greenhaus, Collins, and Shaw (2003), which are time balance, involvement balance, and satisfaction balance. The self-efficacy scale consists of 24 items that are related to the aspects of self-efficacy discovered by Bandura, which are level, strength, and generality.

\section{RESULTS and EXPLANATIONS}

Using data processed with regression analysis, the research found $\mathrm{R}=0.466$ with the value of $p=$ $0.000(p<0.05)$, which means that there is a significant positive effect of self-efficacy towards work-family balance. The second analysis factored in gender, and produced an $\mathrm{R}$ score of 0.464 , with $p$ $=0.014(p<0.05)$, showing a positive and significant effect of self-efficacy to work-family 
balance based on gender. Partial level analysis on female employees if self-efficacy of male employees is controlled produced a value of $p=$ $0.022(p<0.05)$, meaning that self-efficacy levels in female employees have an effect on the workfamily balance of female employees assuming selfefficacy of male employees is controlled. Meanwhile, partial level analysis of male employees if self-efficacy of female employees is controlled produced a value of $p=0.058(p>0.05)$, meaning that self-efficacy levels in male employees have no effect on work-family balance of male employees assuming self-efficacy of female employees is controlled. The effect of self-efficacy towards work-family balance has a total contribution of $21.5 \% .12 .89 \%$ is contributed by female employees, while $8.61 \%$ being contributed by male employees.

Clark (2000) defined work-family balance as a condition where individuals find satisfaction in both their familial roles and work roles, with minimal conflict. Thompson (Cleveland, Cordeiro, Fisk \& Mulvaney, 2006) claimed that supportive work cultures and environments can cause employees to be more effective in balancing their responsibilities, both in their family and in their job, therefore reducing conflicting responsibilities. Male and female employees show a stark difference when it comes to maintaining work-family balances. Female employees are expected to fulfill multiple roles simultaneously, one as a mother to her family, and another as a company employee. Problems arise when the expectations of one role are not aligned or conflict with the expectations of another role. Although male employees are also expected to be fathers and employees, but males tend to be expected to focus on the fulfillment of their workrelated responsibilities, seeing how familial responsibilities are considered to be the responsibility of the mother. The research findings prove that female and male employees differ in maintaining their work-family balance.

Bandura (Feist, 2013) defined self-efficacy as an individual's confidence in their ability to control themselves and their surroundings. Individuals that are confident of their ability to change their surroundings are more likely to take action and have a higher chance of being successful compared to individuals with lower self-efficacy levels. Selfefficacy is not a universal concept, nor can it be generalized like self-esteem or self-confidence. Individuals may have high self-efficacy levels in one situation and low self-efficacy levels in other situations (Feist, 2013). Therefore, we can infer that the majority of the research subjects have a sufficient level of confidence in their capability to work, meaning that these employees are capable enough to handle any problems they may face.

The findings of this research support findings made by Judge, Locke, Durhamn, \& Kluger (1998) which stated that individuals with higher levels of self-efficacy are generally more satisfied with their job and their lives. This is possibly caused by the individual's confidence in their capability to maintain the balance between demands of their job and demands of their non-work related life, therefore achieving a stronger sense of self-efficacy to manage their job and their lives. Their selfefficacy and self-confidence caused them to achieve work-family balance, which in turn allowed them to achieve satisfaction in their work life and their family life.

\section{CONCLUSION}

There is a significant and positive effect of selfefficacy towards work-family balance.

There is also a significant and positive effect of self-efficacy towards work-family balance that is based on gender.

There is an effect of self-efficacy in female employees towards work-family balance assuming gender factors are controlled.

There is no effect of self-efficacy in male employees towards work-family balance assuming gender factors are controlled.

The effect of self-efficacy towards work-family balance has a total contribution of $21.5 \%, 12.89 \%$ are female employees and $8.61 \%$ are male employees.

\section{REFERENCES}

Clark, S. C. (2000). Work/family border theory: A new theory of

work/family balance. Human Relations. 53: 747770.

Cleveland,J.N., Cordeiro,B., Fisk.G \& Mulvaney. R.G. (2006). The role of person, spouse, and organizational climate on work-family perception. Irish Journal of Management. 27(2):229-253.

Delina, G. \& Raya, R.P. (2013). A study on work-life balance in

working women. Internastional Journal of Commerce, Business and Management (IJCBM). 2(5): 274-282.

Dhamayanti, R. (2006). Pengaruh konflik keluargapekerjaan, keterlibatan pekerjaan dan tekanan pekerjaan terhadap kepuasan kerja karyawan wanita studi pada nusantara tour \& travel kantor cabang dan kantor pusat semarang. Jurnal Studi Manajemen \& Organisasi. 3 (2): 93.

Ezra, M. \& Deckman, M. (1996). Balancing work and family

responsibilities: flextime and child care in the federal government. Public Administration Review. 56(2). 174-179

Feist J. \& Feist G.J. (2013). Theories of Personality 7th ed. McGraw

Hill Education. New York. Terjemahan Sjahputri, S.P. 2013. Teori Kepribadian edisi 7 Jakarta: Salemba Humanika.

Greenhause,J.H., Collins,K.M, \& Shaw. J.D. (2003). The relation 
between work-family balance and quality of life. Journal of Vocational Behavior. 3: 510-531.

Grzywacz, J. G., \& Carlson, D. S. (2007). Conseptualizing Work-Family Balance: Implication for Practice and Research. Advances in Developing Human Resource.

Judge, T.A., Kluger, A.N., E.A. Locke \& C.C. Durham. (1998). Dispositional effects on job life satisfaction: the role of core evaluations. Journal of Applied Psychology. 83(1): 17-34.

Kalliath, T., \& Brough, P. (2008), Work-life balance: a review of the meaning of the balance construct. Journal of Management \& Organization. 14(3): 323-327.

Luthans, F. (2011). Organizational behavior (twelfth edision). New

York : The McGraw - Hill Companies.

Nurtjahjanti, H., Mujiasih, E., Prihatsanti, U., Prasetyo, A.R \& Ratnaningsih, Z. (2012). Hubungan antara efikasi diri dan persepsi terhadap pengembangan karir dengan work family conflict pada polwan di polrestabes semarang. Skripsi. Fakultas Psikologi Universitas Diponegoro. Semarang

Paramita, P \& Waridin. (2006). Analisis pengaruh work family balance dan program family friendly terhadap kepuasan kerja studi kasus pada rumah sakit panti wilasa citarum, semarang. Benefit.m10(1).

Sulistyawati,R., Hurtjahjanti,H., \& Prihatsanti,U. (2012). The relationship between work efficacy with job insecurity on production employees pt" $\mathrm{x}$ " semarang. Jurnal Psikologi. 1(1): 139-153.

Warroka, A. \& Febrilia ,I. (2014). Work-family conflict and job performance: lesson from a southeast asian emerging market. Journal of Southeast Asian Research. 2015(2015). DOI: 10.5171/2015.4208 